Egyptian Journal of Rabbit Science, 30(2): 161-175(2020)

\title{
THERAPEUTIC POTENTIAL OF Citrus aurantium ON UROLITHIASIS INDUCED BY ETHYLENE GLYCOL IN MALE RABBITS
}

\author{
Aya Sh. Metwally ${ }^{1}$, Nabil A. Soliman ${ }^{2}$, Amro A. Shalaby ${ }^{2}$ and Anas Y. Hassan ${ }^{3}$ \\ 1 Department of Pharmacology, Faculty of Veterinary Medicine, Aswan \\ University, Egypt. \\ ${ }^{2}$ Department of Zoology, Faculty of Science, Zagazig University, Egypt. \\ ${ }^{3}$ Department of Biology, Faculty of life Science, Tikrit University, Iraq.
}

ABSTRACT: Nephrolithiasis is a complex physicochemical event which starts with urinary supersaturation and then leads to aggregation of renal crystal forming constituents within the kidneys.Researches gives much attention for better medical therapy and assess a satisfactory drug to prevent renal stone formation. The purpose of the study was to detect the effectiveness of Citrus aurantium (bitter orange) juice on ethylene glycol induced nephrolithiasis in male rabbits. Animals were divided into five groups $(n=8)$ in which group 1 as control $(C)$, group 2 as ethylene glycol non treated group (EG), group 3 as ethylene glycol group treated with bitter orange juice $(E G+B . O)$, group 4 as ethylene glycol group treated with Citraforte $(E G+C)$ and group 5 as ethylene glycol group treated with bitter orange juiceand Citraforte $\quad(E G+B . O+C)$. Ethylene glycol was givento group 2-5 in drinking water for $21^{\text {st }}$ days for the induction of kidney stones then the treatments were continued for successive 3 weeks. The obtained results showed a significant increase $(p \leq 0.05)$ in the serum level of total protein, albumin, phosphorus, uric acid, creatinine, blood urea nitrogen BUN,Malondialdehyde (MDA) and a significant decrease in calcium, catalase (CAT), Superoxidase dismutase(SOD) and glutathione (GSH) in the group of rabbits treated with ethylene glycol.All the estimated parameters showed an improvement in their values in the treated groups especially in group 5 which treated with bitter orange juice plus Citra forte. There was a detectable pathological lesion in the kidney tissues of rabbits in ethylene glycol group which improved with treatment by bitter orange juice and or Citraforte.

In conclusion:Co-administration of bitter orange (Citrus aurantium) juice with Citraforte initiated a synergistic action for curing urolithiasis induced by ethylene glycol in male rabbits.

Keywords: Citrus aurantium; Urolithiasis; Ethylene glycol,Calcium oxlalates. 


\section{INTRODUCTION:}

Kidney stones have been associated with an increase renal failure, cardiovascular diseases, diabetes and hypertension (Sigurjonsdottiret al.,2015).Generally, urolithiasis causes crystal aggregation, growth of insoluble particles and may be associated with systemic andmetabolic disorders. Nephrolithiasis withnephrocalcinosis is responsible for 2 to $3 \%$ of end-stage renal cases (Courbebaisseet al.,2016).

Various therapies and investigations are failed to trace out the exact cause and mechanisms of urolithiasis, including thiazide and alkali-citrate that applied to prevent the hyperoxaluria frequency and calculi formation but they are not enough due to low tolerability andlimited effectiveness (Rathodetal.,2012). Several drugs have been used against nephrolithiasis in solitary or in combination with other drugs. However, there is no satisfactory drug to remove the stones. So, researchers give much attention for better medical therapy and to develop a satisfactory drug to prevent stone formation in lithiatic patients (Prathibhakumari and Prasad,2018).

In addition, the surgical techniques disadvantages and limited choice of new pharmacological therapies for the management of kidney stones is worthwhile (Nirumandet al.,2018).Currently, there is no satisfactory drug to cure and/or prevent kidney stone recurrences. Thus, further understanding of the pathophysiology of stone formation to manage urolithiasis using new drugs is necessary (Alelign and Petros,2018).

Consequently, prophylactic management is of great importance to manage urolithiasis (Afsaret al.,2016). The natural role of dietary plants in the prevention of kidney stones, elaborate underlying pharmacological mechanismsand their phytochemical constituents responsible for this activity against stone formation. However, the pharmacological evidence of phytonutrients in dietary plants in the prevention of kidney stones have not been well-established yet (Nirumandet al.,2018).

Citrus aurantium (Rutaceae), the unripe fruit of bitter orange is used in traditional medicine to treat urolithiasis. Previous studies have shown that Citrus aurantium have numerous bioactive compounds, including polymethoxylated flavones (PMFs),flavonoid glycosides, alkaloids, and coumarins. These active components demonstrate pharmacological activity; antioxidant, antimicrobial, anticarcinogenic properties and neuroprotective effects (Stohs,2017).

Citrus aurantiumknown as bitter orange, is usually utilized as a flavoring and acidifying agent for food (Karabiyıkliet al.,2014). It preventsCaOx crystallization and promotes crystal dissolution,possibly through a combination 
of increasing antioxidant levels and antimicrobial activity while decreasing urinary stoneforming constituents, OPN expression, and hypercitraturic effects. Citrus aurantium has attracted the attention of many researchers, and the study of this herb is gradually increasing (Li et al.,2015).

Therefore, this study is aim to evaluate the therapeutic aspect of citrus aurantium or bitter orange juice parallel to standard anti-urolithiatic drug as Citraforte in curing kidney stones and its ability to preventing further stone formation.

\section{MATERIALS AND METHODS:}

Adult male rabbits of New Zealand White (NZW) spp. (600-700 gm) are housed in standard conditions of temperature $\left(22 \pm 2^{\circ}\right)$, relative humidity $(55 \pm 5 \%)$ and light (12 h light-dark cycles) were used. They have been fed with standard pellet diet and water ad libitum. The study protocol was approved by the Institutional Animal Ethics Committee according to the regulation of Committee for the Purpose of Control and Supervision of Experiments on Animals. (Protocol No.: 902 dated: 26/09/2009). The experiment was conducted in accordance with internationally accepted standard guidelines for the use of animals.

\section{Chemicals and Reagent}

Ethylene glycol (EG), Citraforte ${ }^{\circledR}$ powder. Standard estimation kits for calcium, phosphate, uric acid, urea and creatinine(Sigma chemicals, USA). All the other reagents used for analysis were of analytical grade.

\section{Plant material:}

The fruits of Citrus aurantium were purchased from shop at Zagazig,Sharkia, Egypt. Then the fruits prepared to obtain the fresh juice of bitter orange daily during the period of treatment and diluted (1:2) using distilled water (Karoui and Marzouk, 2013).

\section{Ethylene glycol induced urolithiasis model}

Fourty male rabbits (600-700 g) were divided into five groups having eight animals in each. All groups except control were received $0.75 \%$ ethylene glycol in distilled water for 28 days. The standard drug and test drug were given from $15^{\text {th }}$ days for successive 3 weeks (Divakaret al.,2010).

\section{Experimental design:}

Group 1 (C) serve as control group; group 2 (EG) received $0.75 \%$ ethylene glycol only; group 3(EG+B.O)receivedfreshly prepared bitter orange 
juice ( $3 \mathrm{ml}$ of 1:2 diluted juice, twice daily, for each rabbit by oral gavages); group $4(\mathrm{EG}+\mathrm{C})$ receivedcitraforte $(300 \mathrm{mg} / \mathrm{kg}$ body weight) twice daily; group5 (EG+B.O+C)received both freshly prepared bitter orange juice and citraforte with the same doses once daily for successive 3 weeks.

\section{Assessment of antiurolithiatic activity: \\ Serum analysis}

Blood was collected after the experimental period from the retro orbital puncture under ether anesthesia and separation of serum was done by centrifugation at 10,000 rpm for $10 \mathrm{~min}$ and analyzed for urea (Lequanget al., 1987), creatinine (Bowers,1980), uric acid (Hishamet al.,2013) and the blood urea nitrogen was calculated.Serumtotal protein (Yatzidis, 1987)and albumin (Doumaset al., 1997) were estimated. Serum phosphate (Fossatiet al., 1988) and calcium (Parentoniet al.,2001).Antioxidant markers including:(SOD) (Kakkaret al.,1984), catalase (CAT) (Aebi,1984), Glutathione (GSH) (Sedlakand Lindsay,1986), as well as malondialdehyde(MDA) (Okhawaet al., 1979) were performed.

The animals were sacrificed by cervical decapitation and the abdomen was cut open to remove either kidney from each animal. Isolated kidneys were cleaned off extraneous tissue. Then it was preserved in $10 \%$ neutral formalin and undergone to histopathological procedures. The obtained kidney slides were stained by (H\&E),examined under light microscope.

\section{Statistical analysis}

The collected data were analyzed using the SPSS (Statistical Package for Social Sciences) version 15 for Windows ${ }^{\circledR}$ (SPSS Inc, Chicago, IL, USA).Qualitative data was presented as number. Normally distributed data was presented as mean $\pm \mathrm{SD}$. $P<0.05$ was considered to be statistically significant.

\section{RESULTS:}

The obtained results showed a significant increase $(P \leq 0.05)$ in the serum levels of total proteins, albumin and phosphorus in EG group compared to the control group. EG+B.O, EG+C and EG+B.O+C groups showed significant decrease $(P \leq 0.05)$ in total proteins, albumin and phosphorus comparing with the EG group. EG+B.O+C group revealed aninsignificant difference compared to control group.However, the serum calcium levels revealed a significant decrease $(P \leq 0.05)$ in EG group compared to the control 
group. EG+B.O, EG+C and both showed significant increase $(P \leq 0.05)$ comparing with EG group. Rabbits group (EG+B.O+C) revealed aninsignificant difference in level of serum calcium compared to control group (Table 1).

The obtained results in a significant increase $(P \leq 0.05)$ in the serum levels of uric acid, creatinine and urea in EG group 2 compared to the control group. $\mathrm{EG}+\mathrm{B} . \mathrm{O},(\mathrm{EG}+\mathrm{C})$ and $\mathrm{EG}+\mathrm{B} . \mathrm{O}+\mathrm{C}$ groups showed significant decrease $(P \leq 0.05)$ in the level of serum uric acid, creatinine and urea comparing with the EG group. EG+B.O+C group revealed aninsignificant difference in level of serum uric acid, creatinine and urea compared to control group (Table 2). Additionaly, BUNshowed a significant increase $(P \leq 0.05)$ in EG group compared to control. The groups (EG+B.O, EG+C and EG+B.O+C) showed significant decrease $(P \leq 0.05)$ in the level of serum calcium comparing with (EG) group as shown in Figure (1).

There was a significant decrease $(\mathrm{P} \leq 0.05)$ in the serum levels of CAT, SODand GSH in EG group compared to control. EG+B.O, EG+C and $\mathrm{EG}+\mathrm{B} . \mathrm{O}+\mathrm{C}$ groups showed significant increase $(\mathrm{P} \leq 0.05)$ comparing with $\mathrm{EG}$ group. EG+B.O+C group revealed aninsignificant difference in level of antioxidant enzymes compared to control group.Meanwhile, serum level of MDA showed a significant increase $(P \leq 0.05)$ in EG group as compared to control. EG+B.O, EG+Cand $\mathrm{EG}+\mathrm{B} . \mathrm{O}+\mathrm{C}$ showed significant decrease $(\mathrm{P} \leq$ 0.05) in MDA comparing with EG group. EG+B.O+C group revealed aninsignificant difference in level of serum MDA compared to control group (Table 3).

Sections of renal tissues revealed a normal histological structure of kidney in the control group. EG group showed a typical pathological lesions associated with formation of $\mathrm{Ca}$ oxalate crystals including: cystic dilatation of renal tubules, homogenous esinophilic material replaced the necrotic nephrone, focal haemorrhagic area and minute crystals of calcium oxalate between the sloughed epithelial tissues. Kidney sections of EG+B.O group showed a mild renal congestion, degenerative changes in the tubular epithelium, beside shrinkage or lobulationof some glomeruli and very tine $\mathrm{Ca}$ oxalate salts.Moreover, kidney sections from $\mathrm{EG}+\mathrm{C}$ group showed a moderate renal congestion with less degenerative changes in the tubular epithelium and presences of leucocytic infiltrations. Kidney sections of EG+B.O+C group revealed an improvement of all the pathological lesions compared with other treated group and prove a recurrence to the normal histological picture of kidney as in control group (Figure 3). 
Table(1): Effect of Citrus aurantium on serum parameters in urolithiaticrabbits:

\begin{tabular}{||c||c||c||c||c||}
\hline Groups & $\begin{array}{c}\text { Total protein } \\
(\mathrm{g} / \mathrm{dl})\end{array}$ & $\begin{array}{c}\text { Albumin } \\
(\mathrm{g} / \mathrm{dl})\end{array}$ & $\begin{array}{c}\text { Calcium } \\
(\mathrm{mg} / \mathrm{dl})\end{array}$ & $\begin{array}{c}\text { Phosphorus } \\
(\mathrm{mg} / \mathrm{dl})\end{array}$ \\
\hline \hline C & $6.28^{\mathrm{b}} \pm 0.82$ & $3.95 \mathrm{~b} \pm 0.24$ & $12.25 \mathrm{a} \pm 0.78$ & $5.84 \mathrm{~b} \pm 0.53$ \\
\hline \hline EG & $12.08^{\mathrm{a}} \pm 1.9$ & $6.37 \mathrm{a} \pm 1.44$ & $6.79 \mathrm{~d} \pm 0.66$ & $9.09 \mathrm{a} \pm 0.81$ \\
\hline \hline EG +B.O & $7.64^{\mathrm{b}} \pm 0.69$ & $4.67 \mathrm{~b} \pm 0.76$ & $8.72 \mathrm{c} \pm 0.93$ & $8.03 \mathrm{a} \pm 0.44$ \\
\hline \hline EG+C & $7.73^{\mathrm{b}} \pm 1.04$ & $4.47 \mathrm{~b} \pm 0.85$ & $10.08 \mathrm{~b} \pm 1.18$ & $6.47 \mathrm{~b} \pm 0.92$ \\
\hline \hline EG+B.O+C & $6.87^{\mathrm{b}} \pm 1.22$ & $4.22 \mathrm{~b} \pm 0.28$ & $11.76 \mathrm{a} \pm 0.71$ & $6.18 \mathrm{~b} \pm 0.88$ \\
\hline \hline
\end{tabular}

- All data having different letters are significantly different at $\mathrm{p} \leq 0.05$. (Letters "a" represented the highest values, followed by letter " $b "$ and "c").

Table(2): Serum renal tests in urolithiaticrabbits $(n=8)$ :

\begin{tabular}{|c||c|c|c||}
\hline \hline Groups & $\begin{array}{c}\text { Uric acid } \\
(\mathrm{mg} / \mathrm{dl})\end{array}$ & $\begin{array}{c}\text { Creatinine } \\
(\mathrm{mg} / \mathrm{dl})\end{array}$ & $\begin{array}{c}\text { Urea } \\
(\mathrm{mg} / \mathrm{dl})\end{array}$ \\
\hline \hline C & $1.58 \mathrm{c} \pm 0.39$ & $0.96 \mathrm{c} \pm 0.11$ & $22.67 \mathrm{~d} \pm 1.59$ \\
\hline \hline EG & $6.796 \mathrm{a} \pm 1.08$ & $2.84 \mathrm{a} \pm 0.21$ & $62.82 \mathrm{a} \pm 8.81$ \\
\hline \hline EG +B.O & $4.32 \mathrm{~b} \pm 0.69$ & $1.49 \mathrm{~b} \pm 0.40$ & $38.95 \mathrm{~b} \pm 3.76$ \\
\hline \hline EG+C & $3.58 \mathrm{~b} \pm 0.70$ & $1.52 \mathrm{~b} \pm 0.33$ & $32.64 \mathrm{bc} \pm 4.79$ \\
\hline \hline EG+B.O+C & $2.26 \mathrm{c} \pm 0.61$ & $1.28 \mathrm{bc} \pm 0.29$ & $28.37 \mathrm{~cd} \pm 2.05$ \\
\hline
\end{tabular}

- All data having different letters are significantly different at $\mathrm{p} \leq 0.05$. (Letters "a" represented the highest values, followed by letter "b" and "c"). 


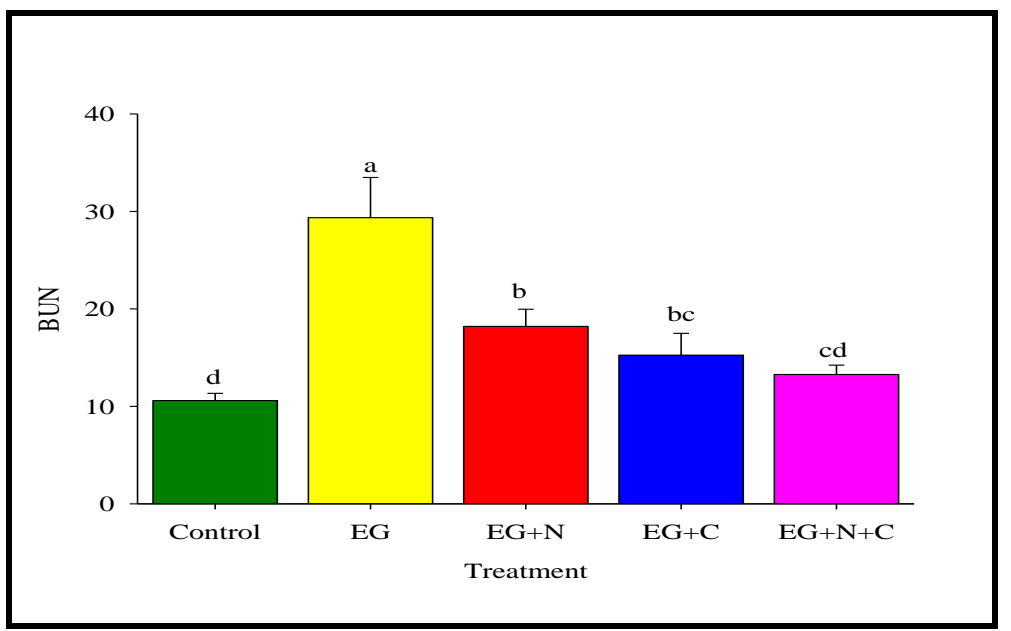

Figure (1): Effects of Citrus aurantium and/or Citraforte on BUN levels of urolithiatic male rabbits in all studied groups.

Table(3): Serum antioxidant markers in urolithiatic rabbits:

\begin{tabular}{|c|c|c|c|c|}
\hline Groups & $\begin{array}{l}\text { CAT } \\
(\mathrm{U} / \mathrm{L})\end{array}$ & $\begin{array}{l}\text { SOD } \\
(\mathrm{U} / \mathrm{ml})\end{array}$ & $\begin{array}{l}\text { GSH } \\
(\mathrm{mmol} / \mathrm{L})\end{array}$ & $\begin{array}{l}\text { MDA } \\
(\mathrm{nmol} / \mathrm{ml})\end{array}$ \\
\hline $\mathbf{C}$ & $299 a \pm 40.88$ & $5.12 a b \pm 0.79$ & $0.99 \mathrm{a} \pm 0.12$ & $6.41 \mathrm{c} \pm 0.60$ \\
\hline $\mathbf{E G}$ & $\begin{array}{c}117.5 \mathrm{c} \pm \\
10.27\end{array}$ & $2.05 \mathrm{~d} \pm 0.16$ & $0.35 c \pm 0.08$ & $\begin{array}{r}13.08 \mathrm{a} \pm \\
1.98\end{array}$ \\
\hline EG +B.O & $\begin{array}{c}249.5 \mathrm{~b} \pm \\
33.42\end{array}$ & $4.39 \mathrm{bc} \pm 0.50$ & $0.63 b \pm 0.19$ & $\begin{array}{r}7.26 \mathrm{bc} \pm \\
0.94\end{array}$ \\
\hline $\mathbf{E G}+\mathbf{C}$ & $\begin{array}{c}212.38 \mathrm{~b} \pm \\
25.92\end{array}$ & $3.93 \mathrm{c} \pm 0.32$ & $0.52 b c \pm 0.12$ & $\begin{array}{r}8.43 \mathrm{~b} \pm \\
1.06\end{array}$ \\
\hline $\begin{array}{c}\mathrm{EG}+\mathrm{B} . \mathrm{O}+ \\
\mathrm{C}\end{array}$ & $\begin{array}{c}305.5 \mathrm{a} \pm \\
45.34\end{array}$ & $5.49 \mathrm{a} \pm 0.63$ & $0.95 a \pm 0.16$ & $6.10 \mathrm{c} \pm 0.58$ \\
\hline
\end{tabular}

- All data having different letters are significantly different at $\mathrm{p} \leq 0.05$. (Letters "a" represented the highest values, followed by letter "b" and "c"). 


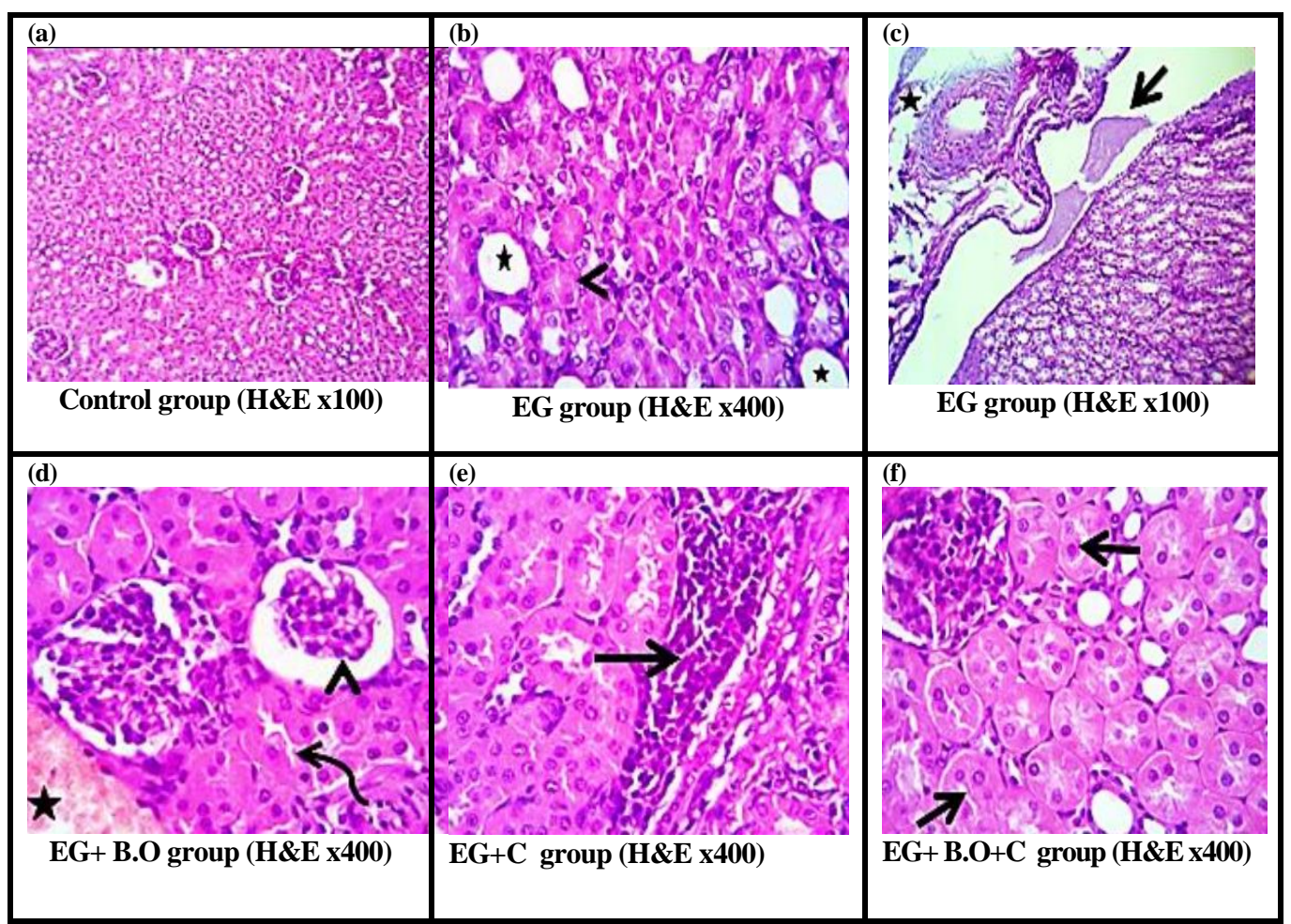

Figure (2): Photomicrograph of kidney sections showing: (a)normalhistomorphological structures of kidney with preserved nephron structures ,stroma and renal pelvis.(b, c) EG group showing cystically dilated renal tubules (star) with degenerative changes of tubular epithelium, homogenous eosinophilic material (arrow) with focally sloughed epithelium (arrow heads) with presence of calcium oxalate crystal on the necrotic epithelial cells. (d) a mild congestion (stars), degenerative changes (curved arrow)in tubular epithelium, shrinkage or lobulation of some glomeruli(arrow head) and perivascular lymphocytic aggregation (arrow) with a minute caoxalate crystals formation and mild edematous and inflammatory reaction. (e) A moderate congested renal blood vessels (star) with degenerative changes in some renal tubular epithelium and presence of leukocytic infiltrations (arrows). (f) A mild congested renal blood vessels (star) with degenerative changes in some renal tubular epithelium with absence of ca oxalate crystals (arrows). 


\section{DISCUSSION:}

The understanding of the pathophysiology of renal lithiasis has great importance in the development of effective and safe anti-nephrolithiatic agents (Prathibhakumari and Prasad,2018).The present study was aimed at evaluating the urolithiatic effects of citrus aurantium (bitter orange) juice as daily intake for dissolving renal stone and prevention of further stone formation parallel to a standard urolithatic agent.

The urolitheatic action of EG is due to a combination ofthe severe metabolic acidosiscaused by glycolic acid and the precipitation of calciumoxalate crystals resulting in impaired organ function, especially in the kidneys (Jacobsen,2005 ).Calcium-oxalate crystals are the most common kidney stones. The mechanisms related to the development of kidney stones are not completely understood (Aggarwal et al.,2013). The causeof kidney stones is multifactorial. The incidence of nephrolithiasis is affecting males and females in both developed and developing countries. This growing trend is believed to be associated with changes in lifestyle modifications such as lack of physical activity and dietary habits (Sofia and Walter,2016).

The oxalic acid precipitates in the kidney in the form of calcium oxalate crystals and is believed to cause physical damage to the renal tubules, primarily in proximal tubule epithelium (Corley et al.,2005). Our results was in agree with Pomara et al.(2008) who stated that renal failure secondary to ethylene glycol depends on the recognitions of the changes of tubular damage in association with calcium oxalate crystals deposition within the tubular epithelial cells and the widespread necrosis of the tubular epithelium in the proximal tubules.

Our results were in agreement with Prabhu et al.(2016)who stated the serum calcium levels of rats treated with ethylene glycol + ammonium chloride groups were significantly decreased $(1.77 \pm 0.01)$ than the rats treated with cystone and /or citrus flavonoid.A possible explanation for this resultis that the formation of $\mathrm{Ca}$ oxalate consumes free calcium (Ca) (Li et al., 2015).

Also, Jacobsen (2005) who stated that, the urolitheatic action of EG is due to a combination of the severe metabolic acidosis caused by glycolic acid and the precipitation of calcium oxalate crystals resulting in impaired organ function, especially in the kidneys. Moreover, Preethi et al. (2010) who mentioned that, the decreased glomerular filtration rate in urolithiatic animals due to obstruction of urine flow by the stones in the urinary system. This causes impairment of renal function resulting in decreased excretion of waste products, such as uric acid.

The obtained results are of the same opinion of Preethi et al. (2010) revealed ethylene glycol + ammonium chloride induces urolithiasis increased 
serum creatinine level. Since, citrus flavonoid decreased the serum creatinine levels significantly compared to the urolithiaticgroup, this suggests the antiurolithiatic activity of citrus flavonoid (Prabhu et al., 2016).

The present results are agree with Ramesh and John (2010) who stated that, it is evident that urolithiasis increases serum BUN. Moreover, Prabhuet al.(2016) concluded that, citrus flavonoid decreased the serum BUN significantly compared to the ethylene glycol in combination with ammonium chloride treated group, reflecting its anti-urolithiatic activity.

The obtained results are concord with Khan (2014) revealed crystals formation can induce the production of reactive oxygen species (ROS) in kidney tissue. The production of ROS can lead to renal epithelial injury, which increases the areas available for crystal attachment and eventual retention within the kidney.

The present results were in agreement with $\mathrm{Li}$ et al.(2015) stated that, SOD was decreased and MDA was increased in EG-treated rats when compared with control rats. After preventive treatment with bitter orange, SOD activity was restored, and MDA levels declined when compared with those in EG treated rats

The obtained results of histopathological examination of kidney sections for control rabbits revealed normal architectures of renal tissues without any pathological changes. Similarly, Saha and Verma (2013) showed no calcifications. The glomeruli, proximal and distal convoluted tubules as well as blood vessels were normal without any inflammatory changes.

Our results was in agree with Pomara et al.,(2008) stated that renal failure secondary to ethylene glycol depends on the recognitions of the changes of tubular damage in association with calcium oxalate crystals deposition within the tubular epithelial cells and the widespread necrosis of the tubular epithelium in the proximal tubules.Ebisuno et al. (1997) demonstrated that crystal-cell interaction resulted in movement of crystals from the tubular lumen into the cells as the results in kidney tissue of crystal adhesion and/or endocytosis. In addition, McMartin and Wallace (2005) reported that calcium oxalate crystals cause damages rat kidney mitochondria and induces the mitochondrial permeability transition. Hence, interference with mitochondrial energy production is a major cause of necrotic cell death.

Thus, the present results refer to the possibility of protection against kidney stones formation by prophylactic and therapeutic use of bitter orange juice daily.

Conclusively, Co-administration of bitter orange (Citrus aurantium) juice with Citra forte initiated a synergistic action for curing urolithiasis induced by ethylene glycol in male rabbits and prevention of newly formed stones. 
The supplementation of Citrus aurantium(bitter orange) juice treated EGinduced urolithiasisin male rabbits as it reduced the growth of urinary stones. The mechanism underlying this effect might be due to its acidic properties, antioxidant, diuretic, and reduction in stone-forming constituents by balancing ions.

\section{REFERENCES:}

Aebi H. (1984). Catalase in vitro. Methods in enzymology, 105, 121-126.

Afsar B., Kiremit M. and Sag A. (2016). The role of sodium intake in nephrolithiasis: epidemiology, pathogenesis, and future directions, European Journal of Internal Medicine, Vol. 35, pp. 16-19.

Aggarwal S. Narula M., Kakkar V. and Tandon C. (2013). Nephrolithiasis: molecular mechanism of renal stone formation and the critical role played by modulators, " BioMed Research International, Vol. 2013, Article ID 29: 29-53, 21 pages.

Alelign T. and Petros B. (2018). Kidney stone disease: an update on current concepts. Advances in urology.doi: 10.1155/2018/3068365. PMID: 29515627; PMCID: PMC5817324.

Bowers D. (1980) Kinetic serum creatinine assays I. The role of various factors in determining specificity. Clinical Chem; 26(5): 551-4.

Corley A., Meek E. and Carney W. (2005). Mode of action: oxalate crystalinduced renal tubule degeneration and glycolic acid-induced dysmor phogenesis - renal and developmental effects of ethylene glycol. Critical reviews in toxicology, 35(8-9), 691-702.

Courbebaisse M., Prot-Bertoye C., Bertocchio P., Baron S., Maruani G., Briand S. and Houillier P. (2016). Nephrolithiasis of adult: from mechanisms to preventive medical treatment. La Revue de Medicine Interne, 38(1), 44-52.

Divakar K., Pawar T., Chandrasekhar B., Dighe B. and Divakar G. (2010). Protective effect of the hydro-alcoholic extract of Rubiacordifolia roots against ethylene glycol induced urolithiasis in rats. Food And Chemical Toxicology, 48(4), 1013-1018.

Doumas, B. T., Watson, W. A., \& Biggs, H. G. (1997).Albumin standards and the measurement of serum albumin with bromcresol green. Clinica Chimica Acta, 258(1), 21-30.

Ebisuno S., Kohjimoto Y., Tamura M., Inagaki T. and Ohkawa T. (1997). Histological observations of the adhesion and endocytosis of calcium oxalate crystals in MDCK cells and in rat and human kidney. Urologia Internationalis, 58(4), 227-231. 
Fossati P, Tarenghi G and Musitelli C. (1988).Enzymatic Colorimetric Method for the Determination of Inorganic Phosphorus in Serum and urine, J .ClinChemClinBiochem; 26: 399.

Hisham H., Zain M., Musa W., Lin C. and Trimbee E. (2013). Spectrophotometric Determination of Uric Acid in Urine Based-Enzymatic Method Uricase with 4-Aminodiphenylamine Diazonium Sulfate (Variamine Blue RT Salt), J. Anal Bioanal Tech.; S7: 11.

Jacobsen D. (2005). Ethylene glycol and other glycols. Critical care toxicology.Brent J. et al., Elsevier Mosby Philadelphia, 869-879.

Kakkar P., Das B. and Viswanathan N. (1984). A modified spectrophotometric assay of superoxide dismutase, Indian $J$ BiochemBiophys ; 21(2): 130-2.

Karabıyıkı Ş., Değirmenci H. and Karapınar M. (2014). Inhibitory effect of sour orange (Citrus aurantium) juice on Salmonella Typhimurium and Listeria monocytogenes. LWT-Food Sci. and Technology, 55(2), 421-425.

Khan R. (2014). Reactive oxygen species, inflammation and calcium oxalate nephrolithiasis. Translational Andrology And Urology, 3(3), 256.

Lequang T., Migueres G., Roche D., Pelladeau L. and Labrousse F. (1987). Improved dye procedure for determining urea concentration by using o-phthalaldehyde and naphthylethylenediamine, ClinChem; 33(1): 192.

Li X., Liang Q., Sun Y., Diao L., Qin Z., Ma B. and Yue Z. (2015). Potential mechanisms responsible for the antinephrolithic effects of an aqueous extract of Fructusaurantii. Evid.-Based Complement. Altern. Med. ;2015:491409. doi: 10.1155/2015/491409. Epub 2015 Jun 15. PMID: 26170875.

Karoui J. I. and Marzouk B. (2013). Characterization of bioactive compounds in Tunisian bitter orange (Citrus aurantium L.) peel and juice and determination of their antioxidant activities. Biomed Res Int. ;2013:345415.

McMartin E. and Wallace B. (2005). Calcium oxalate monohydrate, a metabolite of ethylene glycol, is toxic for rat renal mitochondrial function. Toxicological Sciences, 84(1), 195-200.

Nirumand M., Marziyeh H., Roja R., Mohammad H. and Anupam B.(2018). Dietary Plants for the Prevention and Management of Kidney Stones: Preclinical and Clinical Evidence and Molecular Mechanisms. Int. J. Mol. Sci.; 19, 765pp1-24.

Okhawa H., Ohishi N. and Yagi K. (1979).Assay for lipid peroxides in animal tissues by thiobarbituric acid reaction. Ann Biochem; 95: 351-8. 
Parentoni S., Pozeti S., Figueiredo F. and Faria D. (2001). The determination of total calcium in urine: a comparison between the atomic absorption and the ortho-cresolphtalein complexone methods. Jornal Brasileiro de Patologia e Medicina Laboratorial, 37, 235-238.

Pomara C., Fiore C., D'Errico S., Riezzo I. and Fineschi V. (2008). Calcium oxalate crystals in acute ethylene glycol poisoning: a confocal laser scanning microscope study in a fatal case. Clinical Toxicology, 46(4), 322-324.

Prabhu, V.V.; Sathyamurthy, D.; Ramasamy, A.; Das, S.; Anuradha, M.; Pachiappan, S.(2016).Evaluation of protective effects of diosmin (a citrus flavonoid) in chemical-induced urolithiasis in experimental rats. Pharm. Biol. , 54, 1513-1521.

Prathibhakumari V. and Prasad, G. (2018).Inhibition of $\mathrm{CaOx}$ crystals by Neolamarcki acadamba: An in vivo approach. Bio Rxiv, 253179.

Preethi G., Ahsan S., Gokul P. and Teerthanath S. (2010). Evaluation of reno-protective effects of ethanolic extract of Morinda citrifolia L. in a murine model of gentamicin-induced nephrotoxicity. Int. J. Pharmacol Pharm Technol. ,1:23-28.

Ramesh C.and John E. 2010. Antiurolithiatic activity of wood bark extracts of Cassia fistula in rats. JPBMS 2:1-9.

Rathod N., Biswas D., Chitme H., Muchandi I. and Chandra R. (2012).Antiurolithiatic effects of Punicagranatum in male rats. Journal of Ethnopharmacology, 140, 234-238.

Saha, S.; Verma, R.J. (2013).Inhibition of calcium oxalate crystallisation in vitro by an extract of Bergeniaciliata. Arab J. Urol. , 11, 187-192.

Sedlak L. and Lindsay L. (1986). Estimation of protein-bound and non-protein sulfhydryl groups in tissue with Ellman's reagent. Analytical Biochemistry, 25, pp. 192-205

Sigurjonsdottir K., Runolfsdottir L., Indridason S. and Edvardsson O. (2015).Impact of nephrolithiasis on kidney function. BMC Nephrology, 16(1), 1-7.

Sofia M. and Walter N. (2016). Prevalence and risk factors of kidney stone, Global Journal For Research Analysis, vol. 5, 2016.

Stohs, S. J. (2017). Safety, efficacy, and mechanistic studies regarding Citrus aurantium (bitter orange) extract and p-synephrine. Phytotherapy Research, 31(10), 1463-1474.

Yatzidis L. (1987). Determination of serum total protein. J. Clin. Chem., 23: 908. 


\section{الإمكانات العلاجية لحمضيات الاورانتيوم على التحصي الكلوي المستحث

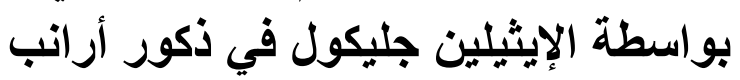
آية شوقي متولي * ـ نبيل عباس سليمان*** ـ عمرو عبد العظيم شلبي***-

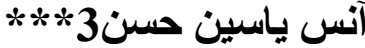

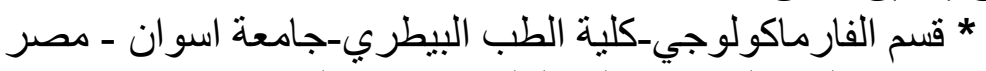

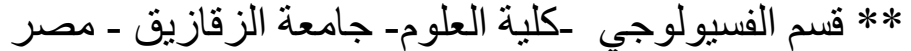

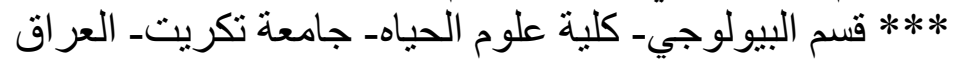

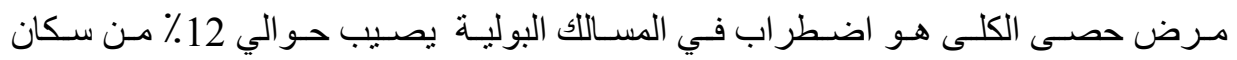

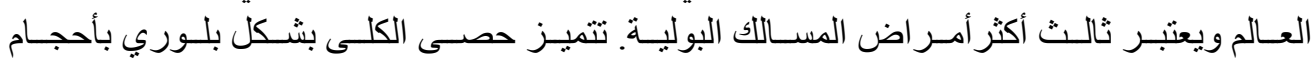

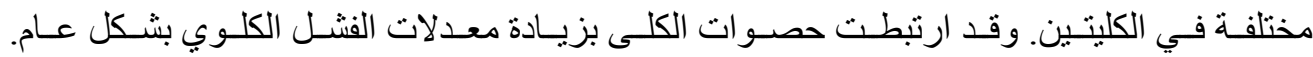

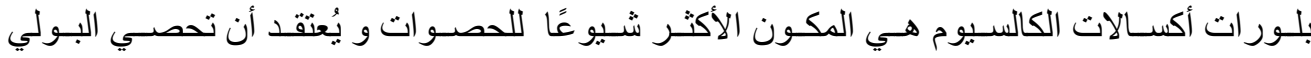

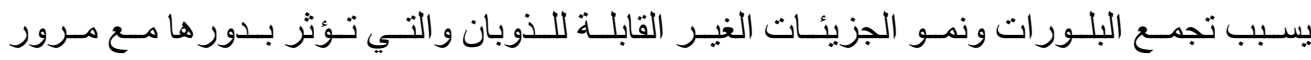

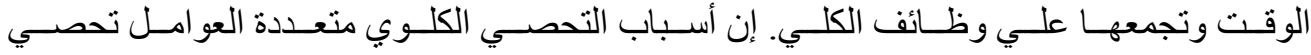

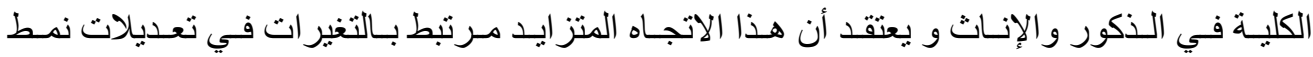

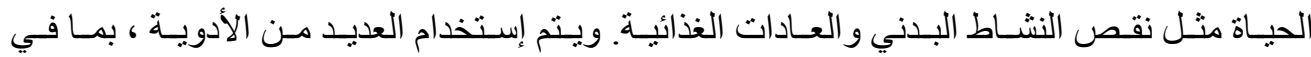

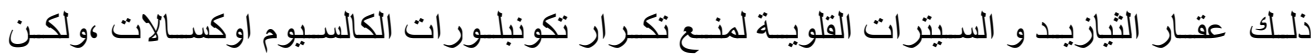

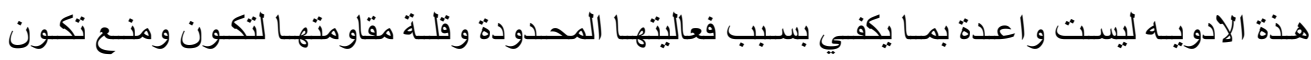

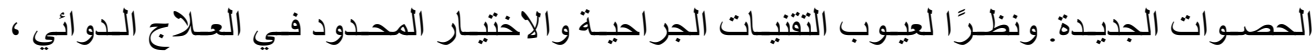

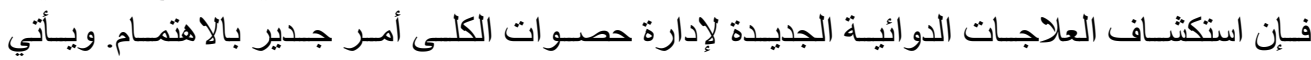

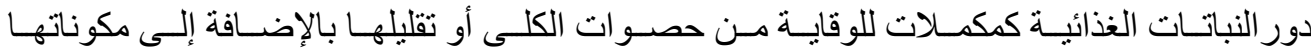

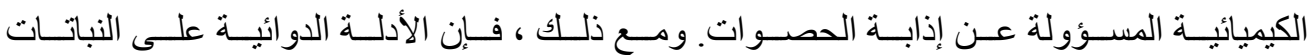

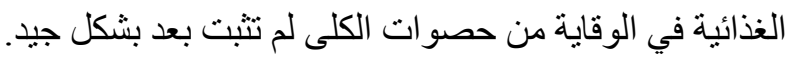

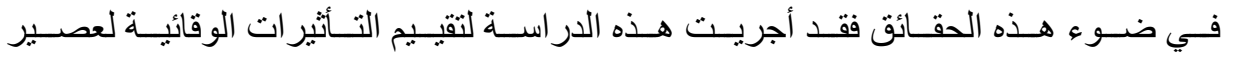

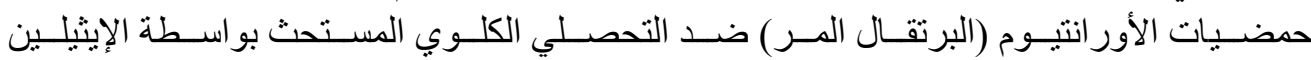

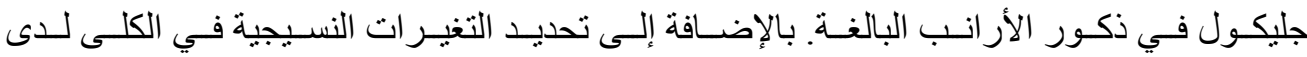

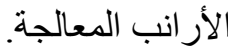
في هذه الدراسة نم أختيار اربعون من ذكور الجرذان البالغة كنموذج لحيوانات التجارب وتم التمان

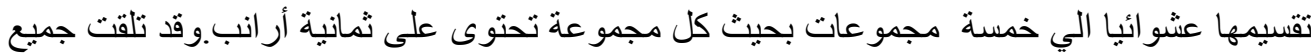

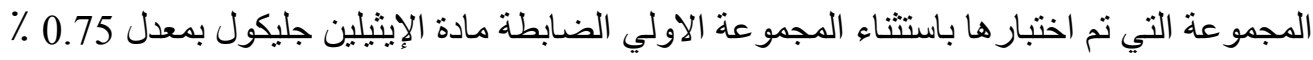

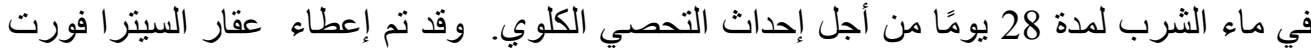
بجر عة (300 mg) لكل كجم من وزن الجسم وكذلك عصير حمضيات الأور انتيوم الطاز ج بجر عة اعلى 3 


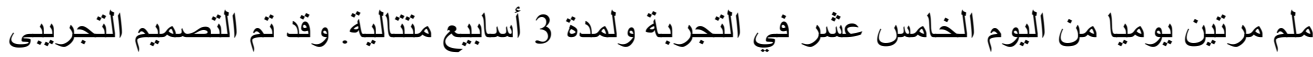

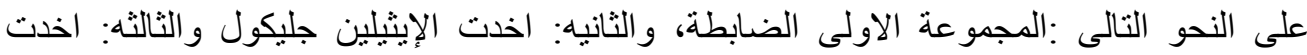

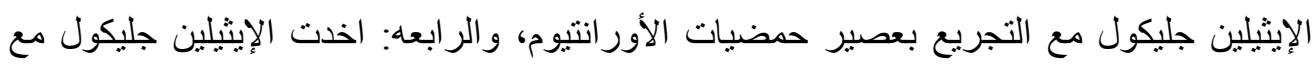

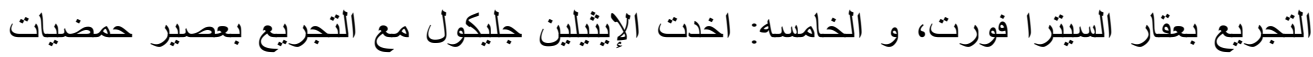

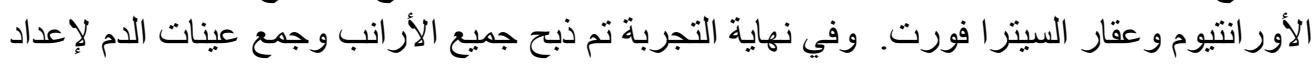

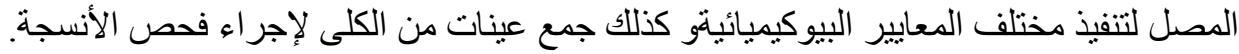

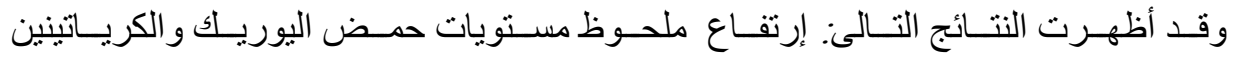

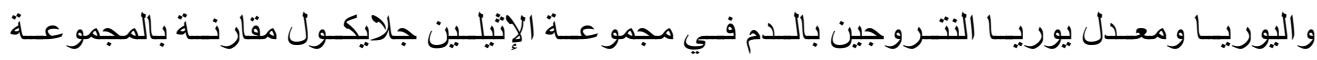

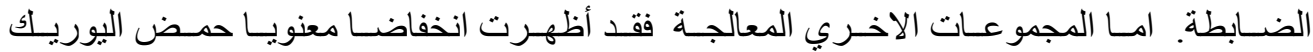

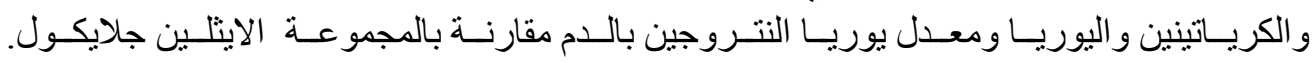

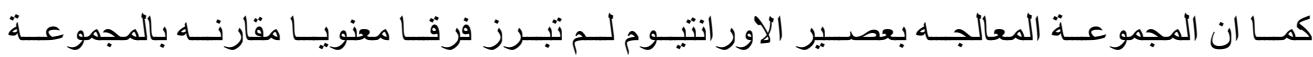

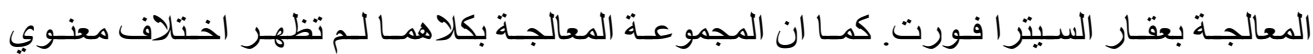

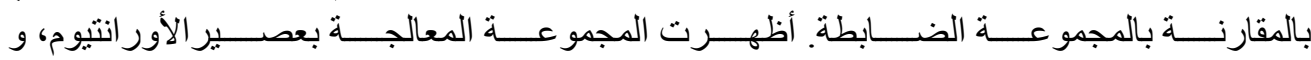

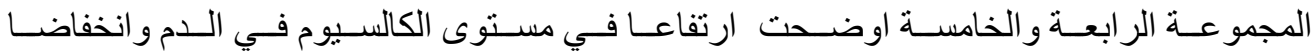

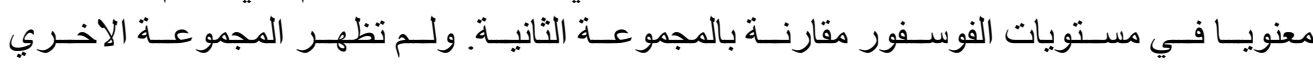

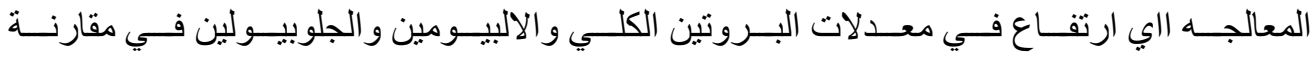

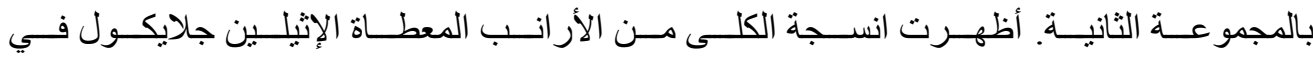

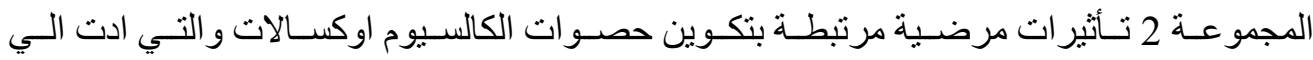

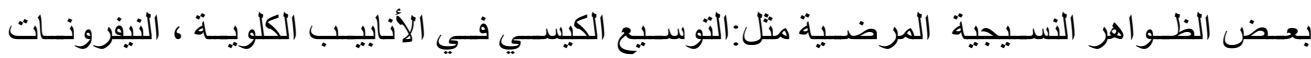

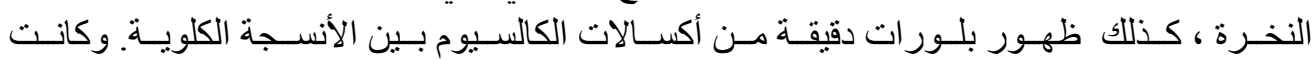

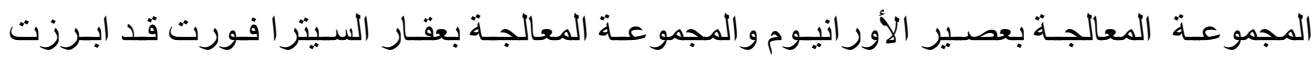

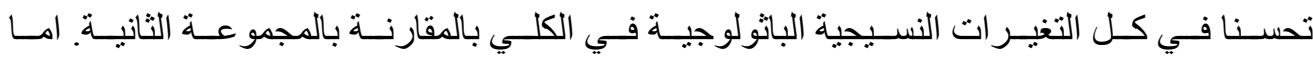

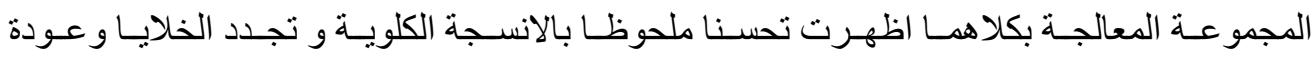
الانسجة لطبيعتها كما في المجمو عة الظابطة.

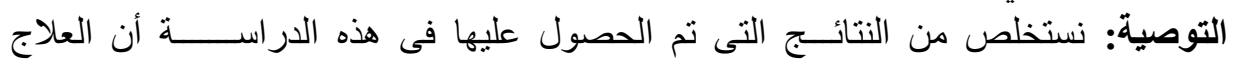

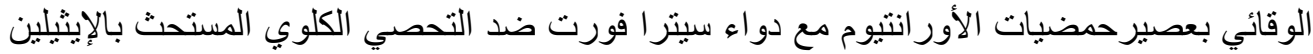

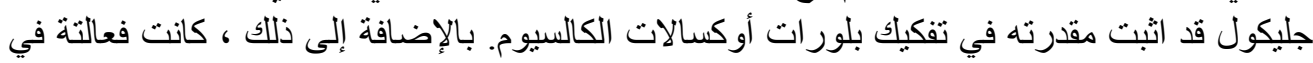
تحسين وظائف النسيج لكلوي وتفي فئليل الاجهاد التاكسدي. 